\title{
O PRINCÍPIO DA REPARAÇÃO E SUA APLICABILIDADE NO ESTADO DO AMAZONAS
}

\author{
Luiz Claudio Pires Costa ${ }^{1}$ \\ Centro Universitário do Norte (UNINORTE)
}

Jucinara Figueiredo Pinheiro ${ }^{2}$

Maternidade Cidade Nova Dona Nazira Daou (MCNDND)

Rubia Silene Alegre Ferreira ${ }^{3}$

Centro Universitário do Norte (UNINORTE)

\section{Resumo}

Artigo recebido em: 31/10/2020.

Artigo aceito em: 22/02/2021.

De relevância tanto nacional quanto internacional, o Direito Ambiental é a fonte dos princípios e mecanismos para que possamos minimizar os danos e impactos negativos ao meio ambiente local e global. O princípio da reparação aqui estudado nos auxilia nesta questão, trazendo uma maior efetividade na eplicabilidade das sançóes por danos ao meio ambiente. Este artigo teve como objetivo a investigaçáo da aplicabilidade do princípio de reparação pela análise de suas proposiçóes, buscando a apresentação da legislação dedicada a esse princípio e sua abrangência, identificando o destino dado aos valores das reparaçôes pecuniárias, a fim de justi- ficar sua cobrança na área ambiental. Para responder a esses objetivos, utilizou-se a revisão bibliográfica - tendo como base a doutrina, a legislação e a jurisprudência. Os resultados apontam para uma obrigação de utilização dos recursos provenientes das sançôes, tanto administrativas quanto judiciais, na reparação ou recomposição aos danos ambientais causados e na manutençáo do equilíbrio ecológico, conforme determinação da nossa Carta Magna.

Palavras chave: Amazonas; aplicabilidade; meio ambiente; princípio; reparação.

1 Mestre em Direito Ambiental pela Universidade do Estado do Amazonas (UEA), Especialista em Direito Eleitoral pela UEA e em Direito Público pelo Centro Integrado de Ensino Superior do Amazonas (CIESA), Graduado em Direito pela Universidade Federal do Pará (UFPA). Professor da graduação em Direito do UNINORTE. Advogado. ORCID: https://orcid.org/0000-0003-2547-2648 / e-mail: luizclaudio.pirescosta@gmail.com

2 Mestranda do Programa de Pós-Graduação em Sociedade e Cultura na Amazônia (PPGSCA) da Universidade Federal do Amazonas(UFAM). Especialista em Psicologia Jurídica pelo UNINORTE. Graduada em Psicologia pelo UNINORTE. Voluntária na MCNDND. ORCID: https://orcid.org/0000-0002-0159-4088 / e-mail: ninna. philos@gmail.com

3 Doutora em Economia, pela Universidade Católica de Brasília (UCB). Mestre em Desenvolvimento Regional pela UFAM. Especialista em População e Desenvolvimento Regional pela UFAM. Graduada em Ciências Econômicas pelo CIESA. Professora do Ensino Superior no UNINORTE. ORCID: https://orcid.org/0000-0001-6786-9948 / e-mail: rubia.alegre.ferreira@gmail.com 


\section{THE PRINCIPLE OF REPARATION AND ITS APPLICABILITY IN AMAZONAS}

\section{Abstract}

Of relevance, both nationally and in order to justify its collection in the internationally, Environmental Law environmental area. To respond to these is the source of the principles and objectives, a bibliographic review was mechanisms so that we can minimize the damage and negative impacts to the local and global environment. The principle of reparation studied here, gives us this assistance, bringing greater effectiveness in the effectiveness of sanctions for damage to the environment. This article aimed to investigate the applicability of the repair by analyzing its forms, seeking the presentation of the legislation related to it and its scope, identifying the destination given to the values of the monetary repairs, carried out based on doctrine, legislation and jurisprudence. The results point to an obligation to use resources from sanctions, both administrative and judicial, in the repair or restoration of the environmental damage caused and the maintenance of ecological balance, as determined by our Constitution.

Keywords: Amazonas; applicability; environment; principle; repair. 


\section{Introdução}

A necessidade de preservação do meio ambiente é verificada a cada dia de maneira mais contundente. No nosso ordenamento jurídico cabe ao Estado e à sociedade, em conjunto, a tutela desse bem, devendo ambos procurarem sempre os meios mais eficazes para a manutenção do equilíbrio ecológico, conforme determina o texto de nossa Constituiçáo Federal de 1988.

Inicialmente, utilizou-se o princípio do poluidor-pagador para impor aos causadores de danos ambientais a indenização por estes, entretanto, considerando as dificuldades de valoração do bem ambiental, haja vista sua grande complexidade, quase sempre as indenizaçóes ficavam bem abaixo do valor necessário para a restituição ou compensação.

Com a finalidade de imprimir maior responsabilização ao infrator, se inicia a utilização do princípio da reparaçáo, o qual atribui ao infrator a obrigação e responsabilidade de efetuar a recuperação da área degradada, restituindo-a a seu estado anterior ou compensando os impactos do dano causado, isso totalmente às suas expensas e sob o controle fiscalizatório jurisdicional, trazendo, assim, uma maior efetividade à recomposição do meio ambiente e cumprindo de maneira mais apropriada, a determinação contida no texto constitucional.

No estudo das normatizaçóes existentes no nosso ordenamento jurídico sobre o Direito Ambiental, encontramos diversos enquadramentos de condutas ilícitas referentes ao meio ambiente, grande parte delas teve como sanção multas e indenizaçóes, mas em quase todas o objetivo de evitar o dano ambiental foi negligenciado, sendo essas medidas tanto repressivas quanto educativas, e considerando que o objetivo básico de toda a legislação deveria ser prioritariamente a recomposição do meio ambiente.

Este artigo teve como objetivo investigar o princípio da reparação e sua aplicabilidade no Amazonas, mais especificamente em Manaus, capital do estado, utilizando-se da análise das legislaçóes, doutrina e jurisprudências relacionadas ao referido princípio, a fim de demonstrar a finalidade e a aplicabilidade das sançôes pecuniárias referentes ao meio ambiente no estado e no município, consoantes à previsão constitucional.

Procurou-se estruturar o trabalho para melhor entendimento do tema, iniciando com as legislaçôes específicas sobre o meio ambiente e sua preservação em todos os âmbitos federativos, em seguida, buscou-se conceituar o princípio da reparaçáo no Direito Ambiental, bem como as formas de reparação, para finalmente demonstrar a aplicabilidade e a destinação dos valores arrecadados com as sançôes pecuniárias ambientais. 


\section{A legislação e as reparaçóes ambientais}

No ordenamento jurídico brasileiro, a matéria sobre o meio ambiente é de competência concorrente, havendo regulamentação sobre o tema nas esferas federal, estadual e municipal.

O texto constitucional, em seu art. 225, já impóe ao Poder Público e à coletividade o dever de defender - tanto às geraçôes atuais quanto às futuras -, a preservação do meio ambiente, acrescentando que este deverá ser ecologicamente equilibrado, o que depende da instituição de um padrão de comportamento que deve ser obedecido por todos.

\subsection{Legislação no âmbito federal}

Ao dispor sobre o meio ambiente, a Constituição Federal reconheceu como direito fundamental o meio ambiente ecologicamente equilibrado em seu art. 225, imputando ao Poder Público a responsabilidade por sua implementação, seja por açôes positivas ou negativas, mas sempre objetivando assegurar o desenvolvimento sustentável. Pretende-se, portanto, aliar o crescimento econômico e a preservação do meio ambiente, para adequar as necessidades das geraçôes atuais e garantir às futuras geraçóes os mesmos recursos.

Com o escopo da preservação do meio ambiente, a legislação brasileira criou direitos e deveres para o Estado e para o cidadáo, além de instrumentos de conservação, entre eles, normas para uso dos diversos ecossistemas e para o desenvolvimento de atividades relacionadas à ecologia, bem como a criaçáo de unidades de conservação.

No âmbito federal, as normas regulamentadoras da proteçáo ao meio ambiente são, entre outras:

A aprovação do Decreto n. 76.389, de 3 de outubro de 1975, que dispunha sobre as medidas de prevenção e controle da poluiçấo industrial, demonstrando, três anos após a Conferência de Estocolmo, que entendia a necessidade de preservação do meio ambiente.

A Lei n. 6.938, de 31 de agosto de 1981, instituiu a Política Nacional do Meio Ambiente, atendendo solicitaçôes preservacionistas da Conferência das $\mathrm{Na}$ çôes Unidas sobre o Ambiente Humano, ocorrida em Estocolmo em 1972. Essa lei, com uma abrangência bem maior que a anterior, pretende implantar um Sistema Nacional para proteção do meio ambiente.

Em 1988 foi promulgada a atual Constituição, chamada de cidadã, por ter 
os direitos fundamentais garantidos em seu texto, institui o meio ambiente ecologicamente equilibrado como direto e dever fundamental do Poder Público e de toda a coletividade, trazendo mecanismos para a manutençâo e preservação deste.

A Lei n. 9.433, de 8 de janeiro de 1997, instituiu a Política Nacional de Recursos Hídricos, que define a água como recurso natural limitado e dotado de valor econômico, prevendo também um Sistema Nacional para coleta, tratamento, armazenamento e informaçóes sobre os recursos hídricos e fatores de sua gestão.

Em 1998 foi sancionada a Lei n. 9.605, de 12 de fevereiro de 1998, que dispóe sobre as sançôes penais e administrativas derivadas das condutas e atividades lesivas ao meio ambiente, reordenando a legislação ambiental no que diz respeito às infraçóes e puniçôes e concedendo-as à sociedade, ao Ministério Público e aos órgãos ambientais, sejam pessoas físicas ou jurídicas.

A Política Nacional de Educação Ambiental instituída pela Lei n. 9.795, de 27 de abril de 1999, foi aprovada para atender à necessidade de construção de valores sociais nos indivíduos, quanto a transmissão de conhecimento, de habilidades, de atitudes e de competências direcionadas à preservaçáo do meio ambiente.

Em 2 de agosto de 2010 foi sancionada a Lei n. 12.305, que instituiu a Política Nacional de Resíduos Sólidos com importantes instrumentos para o enfrentamento dos problemas ambientais, sociais e econômicos decorrentes do manejo inadequado dos resíduos sólidos.

Todas as normas acima citadas foram criadas para preservação do meio ambiente, trazendo uma determinaçáo geral a ser cumprida por todos os setores sociais, sejam entes públicos ou privados, pessoas físicas ou jurídicas, sempre com o objetivo de manutenção desse direito fundamental defendido pela Carta Magna do país.

\subsection{Legislaçáo no âmbito estadual}

Utilizando a competência concorrente elencada no texto constitucional, cabe ao Estado, como ente federativo, regulamentar a legislação federal para aplicação em sua área de atuaçáo, bem como legislar nas áreas que lhe são exclusivas.

No âmbito do estado do Amazonas, há algumas legislaçóes específicas na área de preservação do meio ambiente que não podem deixar de ser citadas, como por exemplo:

- Lei Complementar n. 53, de 5 de junho de 2007. Regulamenta o inc. V do art. 230 e o $\$ 1^{\circ}$ do art. 231 da Constituição Estadual, institui o Sistema Estadual 
de Unidades de Conservação (SEUC), dispondo sobre infraçôes e penalidades e estabelecendo outras providências. Lei Complementar n. 187, de 25 de abril de 2018. Disciplina a execução do Art. 220 da Constituição Estadual, que institui o Conselho Estadual de Meio Ambiente do Estado do Amazonas (CEMAAM) e dispóe sobre o Fundo Estadual de Meio Ambiente (FEMA), e dá outras providências.

- Lei n. 1.463, de 7 de outubro de 1981. Obriga as empresas localizadas em território do estado do Amazonas a se responsabilizarem por danos causados à natureza.

- Lei n. 1.532, de 6 de julho de 1982. Disciplina a Política Estadual da Prevenção e Controle da Poluiçáo, Melhoria e Recuperação do Meio Ambiente e de Proteção aos Recursos Naturais e dá outras providências.

- Lei n. 2.367, de 14 de dezembro de 1995. Art. $2^{\circ}$ - Fica o Chefe do Poder Executivo autorizado a instituir, com as formalidades próprias, o Instituto de Proteção Ambiental do Amazonas (IPAAM) e o Instituto de Diabetologia e Hipertensão Arterial do Amazonas (IDHAM), entidades autárquicas criadas por esta lei. Lei n. 2.416, de 22 de agosto de1996.: Dispóe sobre as exigências para concessão da licença para exploração, beneficiamento e industrialização de produtos e subprodutos florestais com fins madeireiros.

- Lei n. 2.713, de 28 de dezembro de 2001. Dispóe sobre a política de proteção à fauna aquática e de desenvolvimento da pesca e aquicultura sustentável no estado do Amazonas.

- Lei n. 2.908, de 13 de julho de 2004. Dispóe sobre a política de desenvolvimento do ecoturismo e do turismo sustentável no estado do Amazonas.

- Lei n. 2.985, de 18 de outubro de 2005. Regulamenta o Art. 220, $\$ 1^{\circ}$ e $\$ 2^{\circ}$ da Constituiçáo Estadual, institui o Conselho Estadual de Meio Ambiente do estado do Amazonas - CEMAAM e dá outras providências.

- Lei n. 3.118, de 25 de outubro de 2007. Institui o Programa Estadual de Educação Ambiental.

- Lei n. 3.135, de 5 de junho de 2007. Institui a política estadual sobre mudanças climáticas, conservação ambiental e desenvolvimento sustentável do amazonas.

- Lei n. 3.262, de 30 de maio de 2008. Institui o Grupo Estratégico de Combate a Crimes Ambientais (GECAM), definindo suas finalidades, estrutura organizacional, fixando o quadro de cargos comissionados e estabelecendo outras providências. Lei n. 3.785, de 24 de julho de 2012. Dispóe sobre o licenciamento ambiental no estado do Amazonas.

- Lei n. 3.789, de 27 de julho de 2012: Dispóe sobre a reposição florestal no estado do Amazonas. 
- Lei n. 4.266, de 1 de dezembro de 2015. Institui a Política do estado do Amazonas de Serviços Ambientais e o Sistema de Gestão dos Serviços Ambientais, cria o Fundo Estadual de Mudanças Climáticas, Conservação Ambiental e Serviços Ambientais, altera as Leis Estaduais n. 3.135/2007 e n. 3.184/2007, e dá outras providências.

Apesar de todas as leis serem de extrema importância para a preservação do meio ambiente no estado do Amazonas - este, por ser o possuidor da maior diversidade biológica do nosso país -, para o presente estudo, considera-se de maior importância a Lei n. 2.985, de 18 de outubro de 2005, revogada pela Lei Complementar n. 187, de 25 de abril de 2018, responsáveis pela criação do Conselho Estadual de Meio Ambiente e pelo Fundo Estadual de Meio Ambiente, entidades cuja finalidade é receber e administrar dos valores relativos às sançôes administrativas e judiciais por infração às normas ambientais.

\subsection{Legislação no âmbito municipal}

$\mathrm{Na}$ utilização de sua competência constitucional, o município de Manaus conta com várias normas relativas à proteção do meio ambiente, entre elas, elencamos as seguintes:

A Lei n. 605, de 24 de julho de 2001, que instituiu o Código Ambiental do Município de Manaus, sendo o responsável pera estruturação do Sistema Municipal de Proteção ao Meio Ambiente.

Em 10 de março de 2006 foi sancionada a Lei n. 948, que estabeleceu as normas para identificação, catalogação e preservação das nascentes do município, de suma importância para a cidade, já que esta é cortada por diversos cursos d'água de diferentes características, os quais requerem preservação.

A Lei n. 1.192, de 31 de dezembro de 2007, que criou no município o programa de tratamento e uso racional das águas nas edificaçóes, visando induzir à preservação, ao tratamento e ao uso racional dos recursos hídricos nas edificaçóes, tendo em vista a verticalizaçáo do crescimento da cidade, principalmente no que diz respeito às águas servidas.

Em 2009, estabeleceu-se a obrigatoriedade da comprovaçáo da procedência legal da madeira fornecida ao Poder Público em forma de móveis ou instalaçóes, incluindo também sua responsabilidade à administração indireta, por meio da Lei n. 1.358 , de 9 de julho.

A Lei n. 1.451, de 20 de abril de 2010, dispôs sobre a obrigação dos fabricantes e fornecedores de computadores em receber, para reciclagem, os computadores obsoletos descartados pelos consumidores. 
De certo, há mais normas referentes à proteção do meio ambiente, entretanto, das acima citadas, a que tem maior relevância para a proteção ambiental e o persente estudo é a Lei n. 605, de 24 de julho de 2001,que estrutura todo o Sistema Municipal de Proteção ao Meio Ambiente, instituindo o Conselho Municipal de Desenvolvimento e Meio Ambiente (COMDEMA), determinando as fontes do Fundo Municipal para o Desenvolvimento e Meio Ambiente (FMDMA). Em seu inc. VII do art. 73 determina que é receita do presente fundo o produto de condenações judiciais relativas ao meio ambiente.

\section{Direito Ambiental}

Após a Segunda Guerra Mundial, o meio ambiente, em conjunto com a pessoa humana, conseguiram seu lugar junto ao Direito Internacional, nascendo em 1960 o Direito Internacional do Meio Ambiente, entretanto, tal direito somente passou a ser garantido nas Constituiçóes dos diversos países do mundo a partir de 1976 por iniciativa de Portugal, seguido pela Espanha em 1978, pelo Equador e Peru em 1979, Chile e Guiana em 1980, ingressando na Constituição do Brasil em 1988 - embora a proteção do meio ambiente tenha sido uma preocupação antes dessa data, pois o país já dispunha de normas nesse sentido, tendo iniciado a formação do Direito Ambiental pátrio.

Segundo Antunes (2010, p. 9): “o Direito que se estrutura com vistas a regular as atividades humanas sobre o meio ambiente, somente pode ser designado como Direito Ambiental”.

Como em todos os ramos do Direito, os princípios são utilizados como alicerces ou fundamentos, e no Direito Ambiental algumas áreas têm apoio em Declaraçóes Internacionais, constituintes do próprio ramo do Direito, mas entre os princípios, utilizamos para objeto do presente estudo, o da reparação.

\subsection{Princípio da reparaçáo}

A Conferência das Naçóes Unidas sobre o Meio Ambiente e o Desenvolvimento, também conhecida como Eco-92, ocorrida no Rio de Janeiro no ano de 1992, em seu encerramento, com a finalidade de estabelecer uma parceria global, definiu novos níveis de cooperação entre os estados, os setores-chave da sociedade e os indivíduos, ao apresentar uma Declaração contendo vinte e sete princípios.

Preceitua, em seu princípio 13: 
Os estados devem desenvolver legislação nacional relativa à responsabilidade e indenização das vítimas de poluição e outros danos ambientais. Os estados devem, ainda, cooperar de forma expedita e determinada para o desenvolvimento de normas de Direito Internacional Ambiental relativas à responsabilidade e indenização por efeitos adversos de danos ambientais causados, em áreas fora de sua jurisdição, por atividades dentro de sua jurisdição ou sob seu controle (ONU, 1992, p. 156).

É nesse texto que a reparação surge como princípio do Direito ambiental, para que seja "reparado" o meio ambiente degradado, sendo restaurado o dano cometido, cabendo às legislaçôes nacionais dos países partícipes e signatários da Conferência legislar sobre a exigência das medidas de restauração de áreas degradadas e a manutenção de espécies em fase de extinção.

O Brasil já demonstrava ter essa mentalidade preservacionista mesmo antes da Conferência ocorrida em 1992, tendo em vista que, a partir do advento da Lei n. 6.938, em 1981, instituiu-se a Política Nacional do Meio Ambiente, que adotou a responsabilidade objetiva quanto ao meio ambiente:

Art 14 - Sem prejuízo das penalidades definidas pela legislação federal, estadual e municipal, o não cumprimento das medidas necessárias à preservação ou correçấo dos inconvenientes e danos causados pela degradação da qualidade ambiental sujeitará os transgressores:

[...]

$\$ 1^{\circ}$ - Sem obstar a aplicação das penalidades previstas neste artigo, é o poluidor obrigado, independentemente da existência de culpa, a indenizar ou reparar os danos causados ao meio ambiente e a terceiros, afetados por sua atividade. O Ministério Público da Uniáo e dos estados terá legitimidade para propor açáo de responsabilidade civil e criminal, por danos causados ao meio ambiente.

Tal posição foi posteriormente corroborada pela Constituição Federal de 1988 que considera imprescritível a obrigaçáo de reparação aos danos causados ao meio ambiente:

Art. 225. Todos têm direito ao meio ambiente ecologicamente equilibrado, bem de uso comum do povo e essencial à sadia qualidade de vida, impondo-se ao Poder Público e à coletividade o dever de defendê-lo e preservá-lo para as presentes e futuras geraçóes. 


\section{$[\ldots]$}

$\$ 3^{\circ}$ As condutas e atividades consideradas lesivas ao meio ambiente sujeitarão os infratores, pessoas físicas ou jurídicas, a sanções penais e administrativas, independentemente da obrigação de reparar os danos causados.

Fez sua parte o Estado Brasileiro quando instituiu suas normas internas em atenção às necessidades instrumentalizadas nas Conferências Internacionais e instituiu um dos principais princípios do Direito Ambiental interno.

\subsection{Formas de reparação}

O dano ambiental, segundo Milaré (2014, p. 421): “é a lesão aos recursos ambientais, com consequente degradação - alteração adversa ou in pejus - do equilíbrio ecológico e da qualidade de vida”.

Igualado ao dano de qualquer outra espécie, este exige a responsabilidade do causador e as obrigação em repará-lo, assumindo a totalidade dos custos causados pela degradação ambiental.

As formas de reparação do dano ambiental se dividem em duas classes, a primeira denominada restauração natural e a segunda denominada indenização pecuniária.

\subsubsection{Restauração natural}

Verificado o dano ao meio ambiente, a primeira medida a ser explorada é a reconstituição ou reintegração dos bens ambientais danificados, sendo prioridade a busca do retorno do meio ambiente ao "status quo ante".

Também entendem dessa maneira Cardin e Barbosa (2008, p. 159):

A intençấo do legislador é colocar em primeiro plano a recomposição do dano ambiental; apenas quando esta for inviável haverá a indenização, conforme o previsto no inciso VII do art. $4^{\circ}$ da Lei n. 6.938/1981, que dispóe a obrigação do degradador de "recuperar e/ou indenizar os danos causados". Essa também deve ser a interpretaçāo quanto ao disposto no $\$ 1^{\circ}$ do art. 14 da lei referida.

Há várias outras legislaçôes de países como Portugal e Itália que expressam a necessidade de restauração do meio ambiente como forma de reparaçáo, que deve ocorrer às expensas do responsável pelo dano, sempre que houver a possibilidade de aplicação da restauração natural ou da indenização pecuniária, a primeira opção 
deve ser acatada, por ser a melhor para o meio ambiente.

$\mathrm{Na}$ Constituição Federal brasileira, encontramos o fundamento maior para aplicação da restauração natural, no art. 225 , " $\$ 2$ Aquele que explora recursos minerais fica obrigado a recuperar o meio ambiente degradado, de acordo com a solução técnica exigida por órgão público competente na forma da lei".

Mas anteriormente à Constituição, a Lei n. 6.938, de 31 de agosto de 1981, já determinara como um de seus objetivos no art. $4^{\circ}$, VI e VII:

VI - à preservaçấo e restauração dos recursos ambientais com vistas à sua utilização racional e disponibilidade permanente, concorrendo para a manutenção do equilíbrio ecológico propício à vida;

VII - à imposiçáo, ao poluidor e ao predador, da obrigação de recuperar e/ou indenizar os danos causados e, ao usuário, da contribuição pela utilização de recursos ambientais com fins econômicos.

Entretanto, existem duas formas de restauração possíveis: a in natura e a compensação ecológica. A primeira se trata de atividade destinada à reabilitação dos recursos naturais da área degradada, sendo considerada a forma ideal e mais completa de reparação. É executada mediante imposição de obrigação, tendo como objetivo o retorno da capacidade funcional do ambiente degradado, assegurando a autorregeneração da área afetada pela reconstituição dos ecossistemas comprometidos e que foram desequilibrados por causa da lesão.

O dano ambiental se difere dos danos pessoais ou patrimoniais pois não podem ser vistos somente por um ponto de vista econômico, mas sobretudo, ecológico. A recuperaçáo in natura deve ser a primeira a ser utilizada, sendo a compensação monetária sempre considerada uma alternativa subsidiária, a ser utilizada somente quando da responsabilidade de ressarcimento total do dano ambiental. Na maioria dos casos se apresenta como possível a utilizaçáo da reparação in natura e da compensação ecológica.

A segunda opção, a compensação ecológica, também visa à reconstituição do meio ambiente, entretanto, com um efeito de equivalência, por meio da recuperação de outra área distinta da danificada, para compensar o dano ambiental causado.

Normalmente tal estatuto é utilizado quando há irreversibilidade do dano causado na área degredada, impossibilitando a reparação in natura, opta-se pelo estatuto da compensação ecológica.

Tal estatuto se fundamenta no caráter global do meio ambiente, por isso considera que, não havendo possibilidade de recomposição ou recuperação da área 
degradada, poderá ser determinada a recuperação pela compensação de área similar, o que garantiria a permanência da qualidade ambiental do todo.

Também é reconhecido o estatuto da compensação ecológica pelo antigo Código Florestal, Lei n. 7.771, de 15 de setembro de 1965, no inc. III do art. 44, o conceito está presente também no novo código que foi aprovado pela Lei n. 12.651 , de 25 de maio de $2012 \mathrm{em}$ seu art. $48, \$ 2^{\circ}$ e inc. III do art. 66, que se referem à manutenção da Reserva Legal.

A compensação ecológica está presente também no Código do Consumidor, em seu art. 84, que determina que o juiz assegure o resultado prático equivalente ao do adimplemento, trazendo a ideia de equivalência para a atribuiçáo, pelo magistrado, de obrigação de assegurar o resultado prático equivalente à reparação.

\subsubsection{A indenização pecuniária}

A indenização pecuniária tem caráter residual, ou seja, é utilizada em último caso no que diz respeito à reparaçáo do meio ambiente.

A grande dificuldade que esse estatuto traz, principalmente ao magistrado, é a valoração econômica do bem ambiental, que deve ser determinada para que o infrator não saia impune depois de causar o dano, mas sabidamente, a conversão monetária do bem ambiental não é tarefa fácil.

Apesar de ainda não existirem critérios jurídicos definidos para essa atribuição de valores, SENDIM (1998, p. 177) orienta quanto ao que deve ser observado para sua quantificação:

A análise da proporcionalidade das medidas de restauração natural;

A compensação dos usos humanos durante o período de execução da restauração natural; e

A compensaçẫo dos danos ecológicos quando a restauração se revele - total ou parcialmente - impossível ou desfavorável.

Apesar das dificuldades de quantificação dos danos, principalmente os difusos e coletivos, tal fato não deve ser considerado uma barreira para a condenação dos infratores, é nesse sentido que sugere Farias (2014, p. 63), quando cita o enunciado 456 do Conselho de Justiça Federal:

[...] a reparação integral se engrandece, em uma visão prospectiva, como bem evidencia o Enunciado n. 456 do Conselho de Justiça Federal, “a expressão 'dano’ no Art. 944 abrange não só os danos individuais, materiais ou imateriais, mas também os danos sociais, difusos, coletivos e individuais homogêneos". Isso 
significa que a dificuldade de quantificação não será barreira para que se implemente uma sanção reparatória que se aproxime na medida do possível os danos, mesmo que estes possuam natureza metaindividual e que seja necessário somar indenização in natura numa indenização pecuniária, para que se alcance a reparação integral.

A indenização pecuniária é necessária e pode ser exigida cumulativamente com a obrigação de recomposiçáo do meio ambiente degradado para compensação de dano moral coletivo, já havendo nesse sentido jurisprudência do Superior Tribunal de Justiça em seu informativo 526:

DIREITO PROCESSUAL CIVIL E AMBIENTAL. CUMULAÇÃO DAS OBRIGAÇÓES DE RECOMPOSIÇÃO DO MEIO AMBIENTE E DE COMPENSAÇÃO POR DANO MORAL COLETIVO.

$\mathrm{Na}$ hipótese de ação civil pública proposta em razão de dano ambiental, é possível que a sentença condenatória imponha ao responsável, cumulativamente, as obrigaçóes de recompor o meio ambiente degradado e de pagar quantia em dinheiro a título de compensação por dano moral coletivo. Isso porque vigora em nosso sistema jurídico o princípio da reparação integral do dano ambiental, que, ao determinar a responsabilização do agente por todos os efeitos decorrentes da conduta lesiva, permite a cumulação de obrigaçôes de fazer, de não fazer e de indenizar. Ademais, deve-se destacar que, embora o art. $3^{\circ}$ da Lei 7.347/1985 disponha que "a ação civil poderá ter por objeto a condenação em dinheiro ou o cumprimento de obrigaçấo de fazer ou não fazer", é certo que a conjunçấo "ou" - contida na citada norma, bem como nos arts. $4^{\circ}$, VII, e $14, \$ 1^{\circ}$, da Lei 6.938/1981 opera com valor aditivo, não introduzindo, portanto, alternativa excludente. Em primeiro lugar, porque vedar a cumulaçáo desses remédios limitaria, de forma indesejada, a Ação Civil Pública importante instrumento de persecução da responsabilidade civil de danos causados ao meio ambiente -, inviabilizando, por exemplo, condenaçóes em danos morais coletivos. Em segundo lugar, porque incumbe ao juiz, diante das normas de Direito Ambiental - recheadas que são de conteúdo ético intergeracional atrelado às presentes e futuras geraçóes -, levar em conta o comando do art. $5^{\circ} \mathrm{da}$ LINDB, segundo o qual, ao se aplicar a lei, deve-se atender "aos fins sociais a que ela se dirige e às exigências do bem comum", cujo corolário é a constatação de que, em caso de dúvida ou outra 
anomalia técnico-redacional, a norma ambiental demanda interpretação e integração de acordo com o princípio hermenêutico in dubio pro natura, haja vista que toda a legislação de amparo dos sujeitos vulneráveis e dos interesses difusos e coletivos há sempre de ser compreendida da maneira que lhes seja mais proveitosa e melhor possa viabilizar, na perspectiva dos resultados práticos, a prestação jurisdicional e a ratio essendi da norma. Por fim, a interpretação sistemática das normas e princípios ambientais leva à conclusão de que, se o bem ambiental lesado for imediato e completamente restaurado, isto é, restabelecido à condição original, não há falar, como regra, em indenização. Contudo, a possibilidade técnica, no futuro, de restauração in natura nem sempre se mostra suficiente para reverter ou recompor integralmente, no âmbito da responsabilidade civil, as várias dimensóes do dano ambiental causado; por isso não exaure os deveres associados aos princípios do poluidor-pagador e da reparação integral do dano. Cumpre ressaltar que o dano ambiental é multifacetário (ética, temporal, ecológica e patrimonialmente falando, sensível ainda à diversidade do vasto universo de vítimas, que vão do indivíduo isolado à coletividade, às geraçôes futuras e aos processos ecológicos em si mesmos considerados). Em suma, SEGUNDA TURMA equivoca-se, jurídica e metodologicamente, quem confunde prioridade da recuperaçáo in natura do bem degradado com impossibilidade de cumulaçáo simultânea dos deveres de repristinação natural (obrigação de fazer), compensação ambiental e indenização em dinheiro (obrigação de dar), e abstenção de uso e nova lesão (obrigação de não fazer). REsp 1.328.753-MG, Rel. Min. Herman Benjamin, julgado em 28/5/2013.

Assim, verificamos a importância da indenização pecuniária, considerando que mesmo com a reparaçáo do dano ambiental in natura, pode ocorrer a necessidade da indenização do dano social ou moral, coletivo ou individual, devendo, assim, serem considerados todos os aspectos da reparaçáo, trazendo também a possibilidade da monetarização do dano e sua consequente indenização.

\section{APLICABILIDADE E DESTINAÇÁO DAS REPARAÇÓES AMBIENTAIS}

Inicialmente, é necessário demonstrar que é a responsabilidade que determinará a reparação do dano, entretanto a responsabilidade civil ambiental apresenta 
algumas especificidades se comparada com a responsabilidade civil elencada no nosso Código Civil, abaixo demonstraremos algumas delas.

\subsection{A responsabilidade civil ambiental}

Tal responsabilidade conta com um regime jurídico próprio, fundamentado na Constituição Federal de 1988 e na Lei n. 6.938, que diverge em muitos pontos do regime comum previsto tanto no Código Civil quanto no Direito Administrativo.

Apresentaremos aspectos a serem considerados sobre a responsabilidade, a exemplo, esta é consagrada como objetiva do degradador, sendo decorrente do simples risco ou fato da atividade, independentemente de haver culpa do agente. Também há de ser considerada a amplitude inovadora dada pela Lei 6.938, que considera poluidor a pessoa física ou jurídica, de direito público ou privado, que seja direta ou indiretamente responsável pelo dano ao meio ambiente. Sobretudo, os efeitos da responsabilidade abrangem a reparação do meio ambiente e também a cessação imediata do fato que gere o dano, tendo lugar, assim, a aplicaçáo do princípio da reparaçáo integral do dano.

Em algumas situaçôes, torna-se impossível o retorno da qualidade ambiental ao estado em que se encontrava antes do dano, restando uma sequela que náo pôde ser totalmente eliminada, o que requer a aplicação de compensaçáo.

A reparaçáo integral do dano ambiental abrange toda a extensão dos danos produzidos em consequência do fato causador, o que inclui seus efeitos ambientais e ecológicos, a perda da qualidade ambiental desde sua ocorrência até a recomposição efetiva do meio ambiente, a consideração de todos os futuros danos ambientais que estiverem determinados cientificamente como certos, a compensação pelos danos irreversíveis e pelos danos morais coletivos resultantes da degradaçáo do meio ambiente.

O STF também entendeu dessa maneira quando, em julgamento, o Ministro Herman Benjamim decidiu além, considerando que a reparação integral do dano ambiental comporta também a restituição ao patrimônio público quanto ao proveito econômico afetado pelo empreendimento danoso, a mais-valia ecológica, que foi indevidamente auferida pelo degradador.

Cabe ressaltar que a responsabilidade civil ambiental goza de um sistema especial de regras sobre a matéria, diferente em alguns pontos das normas gerais determinadas pelo Código Civil, pois a Constituição e a Lei 6.938 não incluíram nenhuma exceção ou norma de redução da reparação integral do dano, não podendo por isso utilizar-se o regime geral determinado pelo diploma Civil. 
Lembremos que tem como fundamento a responsabilidade civil ambiental, o risco que as atividades danosas criaram será o fator relevante para determinar a reparação a ser executada, e não a culpa do agente.

Outro estatuto da responsabilidade civil que náo pode ser utilizado na responsabilidade ambiental é o da transação, pois como na lei civil, esta está adstrita aos direitos patrimoniais de natureza privada, o que a incompatibiliza com o caráter do direito ao meio ambiente ecologicamente equilibrado, determinado pela Constituição Federal como direito fundamental e bem de uso comum do povo.

Resumindo, a reparaçáo do dano ao meio ambiente deve, na medida do possível, retorná-lo à situação em que seriam todos beneficiados se não houvesse dano, tendo a reparação total aplicaçáo, refletindo não apenas o dano causado diretamente ao bem ou meio ambiente, mas toda a extensão dos danos provenientes do ato cometido, sendo incluído o dano moral, ambiental e a reparabilidade ilimitada do dano causado, sendo o meio ambiente um bem indisponível.

\subsection{Aplicabilidade das reparaçóes ambientais}

Como verificamos, comprovada a existência de dano ambiental, fica o causador responsável pelo ressarcimento de tal dano, sendo utilizada preferencialmente a reparação in natura do meio ambiente degradado e, somente na impossibilidade total de sua reparação é que será atribuída pena pecuniária.

$\mathrm{O}$ dever de indenização se encontra previsto em diversos diplomas legais, inclusive na Constituição, todas buscando a recomposição, devendo o infrator restaurar e reintegrar o patrimônio ambiental lesado, objetivo principal das legislaçôes a preservação do meio ambiente.

Nem sempre a separação pela restauração natural das espécies é possível, pois os bens ambientais apresentam uma grande complexidade. Quando o dano for irreversível e não houver possibilidade da restituiçáo, poderá ser buscada a compensaçấo equivalente daqueles bens ambientais lesados, devendo ser compensado o dano ao bem ambiental com a restituição do bem ambiental, priorizando a recuperação da qualidade ambiental global.

Entretanto, na impossibilidade da realização da reparação por reconstituiçáo ou por compensação, é que se deve optar pela indenização pecuniária, considerada uma forma indireta de reparação do dano. Todas as hipóteses aqui elencadas traduzem a busca do legislador em impor um custo ao infrator ou poluidor, sempre com dois objetivos específicos: responder economicamente aos danos causados à natureza e apresentar medida educativa, evitando que se reproduzam comportamentos semelhantes. 
Tal aplicação procura ultrapassar a indenização e chegar à fruição plena do meio ambiente. A indenização não possibilita, em alguns casos, a recomposição do dano como bem natural, tal lesão ambiental vai além da ilicitude ao atingir uma grande coletividade que não tem qualquer relação com o ato, mas que restará prejudicada.

\subsection{Destinaçáo da reparaçáo}

A Lei n. 7.347 (Lei da Ação Civil Pública), de 24 de julho de 1985, é clara quando estabelece em seu art. 13:

Art. 13. Havendo condenação em dinheiro, a indenização pelo dano causado reverterá a um fundo gerido por um Conselho Federal ou por Conselhos Estaduais de que participarão necessariamente o Ministério Público e representantes da comunidade, sendo seus recursos destinados à reconstituição dos bens lesados.

A norma se refere ao Fundo Federal de Defesa dos Direitos Difusos (FDDD), bem como aos Fundos Estaduais e Municipais, já que a competência relativa ao meio ambiente é concorrente.

$\mathrm{Na}$ esfera Federal, tal fundo foi regulamentado por meio do Decreto $\mathrm{n}$. 1.306, de 9 de novembro de 94, que sofreu alteraçôes pela Lei n. 9.008, de 21 de março de 1995, a qual criou o Conselho Federal Gestor do Fundo de Direitos Difusos, sendo, conforme o art. $2^{\circ}$ :

Art. 2० O CFDD, com sede em Brasília, será integrado pelos seguintes membros:

I - um representante da Secretaria de Direito Econômico do Ministério da Justiça, que o presidirá;

II - um representante do Ministério do Meio Ambiente, dos Recursos Hídricos e da Amazônia Legal;

III - um representante do Ministério da Cultura;

IV - um representante do Ministério da Saúde, vinculado à área de vigilância sanitária;

$\mathrm{V}$ - um representante do Ministério da Fazenda;

VI - um representante do Conselho Administrativo de Defesa Econômica - CADE;

VII - um representante do Ministério Público Federal;

VIII - três representantes de entidades civis que atendam aos pressupostos dos incisos I e II do art. 5 da Lei n. 7.347, de 1985. 
O funcionamento do Conselho é regulado pelo Poder Executivo, tendo como atribuição principal zelar pela aplicação dos recursos na consecução dos objetivos previstos no art. $3^{\circ}$ da Lei.

Como pode ser verificado no art. $1^{\circ}$ da Lei, o objetivo do Fundo não é exclusivamente voltado para os interesses do Direito Ambiental, englobando como o próprio nome diz, os interesses difusos. Estabelece o $\$ 1^{\circ}$ do mesmo artigo:

$\$ 1^{\circ} \mathrm{O}$ Fundo de Defesa de Direitos Difusos (FDD), criado pela Lei $\mathrm{n}$. 7.347, de 24 de julho de 1985 , tem por finalidade a reparação dos danos causados ao meio ambiente, ao consumidor, a bens e direitos de valor artístico, estético, histórico, turístico, paisagístico, por infração à ordem econômica e a outros interesses difusos e coletivos.

No $₫ 3^{\circ}$ determina as formas e finalidades de aplicação dos recursos, tendo uma mera menção à recuperação:

$\$ 3^{\circ}$ Os recursos arrecadados pelo FDD serão aplicados na recuperaçáo de bens, na promoção de eventos educativos, científicos e na edição de material informativo especificamente relacionado com a natureza da infração ou do dano causado, bem como na modernizaçấo administrativa dos órgãos públicos responsáveis pela execução das políticas relativas às áreas mencionadas no $₫ 1^{\circ}$ deste artigo (grifo nosso).

Fiorillo (2013, p. 749) corrobora que, a ênfase a ser dada é a da recuperação e não de compensação pecuniária quando menciona: "os recursos arrecadados nos fundos deverão ser aplicados, tanto quanto possível, na recomposição dos danos ou, havendo impossibilidade, empregados de forma a cumprir sua finalidade".

Apesar do entendimento de que as demais unidades da federação estariam autorizadas à criação de fundo semelhante em suas áreas de atuação, não há na norma qualquer autorização para que seja dada destinação diversa que não seja a de reconstituir os bens lesados.

Entretanto, o Superior Tribunal de Justiça não entendeu dessa maneira, quando determinou que os recursos do Fundo do Estado de São Paulo fossem utilizados para custear atividade pericial em Ação Civil Pública de danos ambientais.

PROCESSUAL CIVIL - ADMINISTRATIVO - RECURSO ORDINÁRIO EM MANDADO DE SEGURANÇA - AÇÃO CIVIL PÚBLICA - PARCELAMENTO IRREGULAR DE SOLO EM ÁREA DE MATA ATLÂNTICA - DECISÃO JUDICIAL RELATIVA A HONORÁRIOS PERICIAIS RECORRIBILIDADE - SÚMULA 267/STF. 1. Mandado de 
segurança impetrado contra decisáo judicial proferida em autos de ação civil pública - ajuizada pelo Ministério Público do Estado de São Paulo visando evitar a ocorrência de possíveis danos ambientais decorrentes da realizaçáo de parcelamento do solo em área de vegetação de mata atlântica -, mediante a qual se determinou que as despesas com a realização da perícia judicial fossem custeadas com recursos do Fundo Estadual de Reparação de Interesses Difusos Lesados. 2. "Não cabe mandado de segurança contra ato judicial passível de recurso ou correção" (Súmula 267/STF). Hipótese em que o próprio Ministério Público Estadual interpôs agravo de instrumento, ao qual fora atribuído efeito suspensivo, contra a decisão impugnada. 3. Inexistência de circunstância capaz de qualificar a decisão impugnada como manifestamente ilegal ou teratológica, pois a Primeira Seção desta Corte, no julgamento dos EREsps 733.456/SP e 981.949/RS, ocorrido na assentada do dia 24 de fevereiro de 2010, decidiu que, conquanto não se possa obrigar o Ministério Público a adiantar os honorários do perito nas ações civis públicas em que figura como parte autora, diante da norma contida no art. 18 da Lei 7.347/85, também não se pode impor tal obrigação ao particular, tampouco exigir que o trabalho do perito seja prestado gratuitamente. 4. Diante desse impasse, afigura-se plausível a solução adotada no caso, de se determinar a utilizaçáo de recursos do Fundo Estadual de Reparação de Interesses Difusos Lesados, criado pela Lei Estadual 6.536/89, considerando que a ação civil pública objetiva interromper o parcelamento irregular de solo em área de mata atlântica, ou seja, sua finalidade última é a proteção ao meio ambiente e a busca pela reparação de eventuais danos que tenham sido causados, coincidentemente com a destinação para a qual o Fundo foi criado. 5. Recurso ordinário não provido (STJ - RMS 30812/SP, Rel. Ministra ELIANA CALMON, SEGUNDA TURMA, julgado em 04/03/2010, DJe 18/03/2010).

$\mathrm{Na}$ análise da lei, verifica-se que suas finalidades não são específicas, necessitando uma melhor regulamentação a fim de evitar entendimentos destoantes, o que pode resultar na inexistência de uma forma eficaz de aplicabilidade e averiguação de sua destinação correta.

No âmbito do estado do Amazonas foi a Lei n. 2.985, de 18 de outubro de 2005, instituiu o Conselho Estadual do Meio Ambiente do Estado do Amazonas (CEMAAM), criando também em seu art. 27 o Fundo Estadual do Meio 
Ambiente (FEMA), destinado a carrear recursos para a proteção e conservação do meio ambiente, determinando duas de suas fontes de receita: o produto das sanções administrativas e judiciais por infração às normas ambientais e as parcelas de compensaçôes ambientais.

Tal norma foi revogada pela Lei Complementar n. 187, de 25 de abril de 2018, que trouxe uma grande redução no quantitativo de integrantes do plenário do Conselho, mantendo o FEMA e suprimindo o inciso que determinava como uma de suas fontes as parcelas de compensaçôes ambientais, substituindo-as por "outras receitas eventuais, incluídas doaçôes".

A nova legislação também ampliou a destinação dos recursos do FEMA, antes somente "para a proteção e conservação do meio ambiente" e agora para a "realização das atividades de conservação, recuperação, melhoria, educação, monitoramento e fiscalização ambiental, inclusive da articulação intersetorial”, destoando sua destinação primária que é a proteção e a recomposição do meio ambiente.

É para esse fundo que são destinadas todas as indenizaçóes pecuniárias pagas, provenientes das decisóes judiciais e da esfera administrativa.

O Município de Manaus também criou seu conselho Municipal de Desenvolvimento e Meio Ambiente (COMDEMA), por meio da Lei n. 605, de 24 de julho de 2001, que instituiu o Código Ambiental do Município de Manaus. Tal Código foi o responsável pela implantação do Sistema Municipal do Meio Ambiente - SIMMA, tendo como órgão colegiado de caráter consultivo e deliberativo também o COMDEMA.

Tal Código é bem completo no que diz respeito à proteção do meio ambiente, o que pode ser constatado pela criação do sistema de informaçóes ambientais para auxílio dos trabalhos da Secretaria específica, bem como pelo levantamento das necessidades do município, açóes que proporcionaram à administração um conhecimento maior e, consequentemente um melhor poder de decisão.

Criou-se também o Fundo Municipal para o Desenvolvimento e Meio Ambiente (FMDMA), com a finalidade de prover condiçôes financeiras e gerenciar os recursos para o desenvolvimento de serviços e açóes relativos ao meio ambiente como um todo, tendo também como uma de suas receitas, o produto de condenaçôes de ações judiciais relativas ao meio ambiente. A utilização do Fundo é diversificada, não o destinando especificamente para a reparaçáo e conservação do meio ambiente.

Como pode ser verificado pelo exposto, todos os valores recebidos pelo Estado por determinação judicial ou administrativa, que tenham relação com o meio ambiente, serão destinados a um Fundo específico, criado especialmente para a reparaçáo e compensação do dano ambiental causado por infratores, cabendo ao 
Poder Público sua gerência e utilização correta, para garantir o atendimento de sua finalidade.

\section{Conclusão}

A legislação brasileira, há algum tempo se preocupa com a preservação do meio ambiente, o que ficou evidente com a inclusão de artigos no texto constitucional, cuja determinação é defendê-lo e preservá-lo, tanto para as geraçóes atuais quanto para as futuras, impondo tal obrigação ao Poder Público. Importante recordar que tal responsabilidade cabe a cada um de nós, como cidadáos, em preservar o equilíbrio ecológico do Brasil. Com o surgimento do Direito Ambiental, nasce um novo ramo do Direito, um garantidor da proteção ao meio ambiente, que tem por finalidade nos orientar sobre a possibilidade e dever em utilizar os recursos naturais de maneira sustentável, ou seja, prevendo a conservação deste.

Entre os princípios desse novo ramo do Direito está o da reparação, exigindo daqueles que se configurem como infratores, a recomposiçáo do meio ambiente que tenham degradado. Várias formas de reparação surgiram, sendo divididas em duas classes, a primeira e prioritária é denominada restauração natural, que pode ser executada pela restauração in natura ou por meio da compensação ambiental, já a segunda, denominada de indenização pecuniária, deve ser utilizada de maneira residual ou na impossibilidade de recomposição do meio ambiente degradado.

É necessário que sejam aplicados os princípios de responsabilidade civil ambiental para que as devidas sançôes sejam aplicadas e o infrator recupere os danos cometidos. A lei prevê que essa responsabilidade abranja toda a extensão dos danos produzidos, incluindo os efeitos ambientais e ecológicos, a perda da qualidade ambiental, a responsabilização pela recomposição efetiva da área afetada, a ponderação sobre os danos ambientais futuros que possam ser previstos cientificamente, a compensação pelos danos irreversíveis e pelos danos morais coletivos resultantes da degradação.

Pela grande dificuldade de valoraçáo ambiental por causa de sua complexidade é que se torna preferível a determinação da reparação, devendo a pena pecuniária ser determinada somente no caso de irreversibilidade do dano e dada impossibilidade de restituiçáo, como forma indireta de reparação.

Em 1981 a Lei n. 6.938, já obrigava o poluidor a indenizar ou reparar os danos causados ao meio ambiente e à terceiros, mas somente em 1985, por meio da Lei n. 7.347, da Ação Civil Pública, é que fica estabelecida a criação de um Fundo para a administração dessas condenações pecuniárias, sendo este regulamentado somente em 1994, por meio do Decreto n. 1.306. 
Apesar da demora, tanto da União quanto dos estados e municípios em criar o fundo, atualmente há uma destinação correta para todas as indenizaçóes pecuniárias advindas de causas judiciais ou de sançóes administrativas. No estado do Amazonas existem tanto o FEMA quanto o FMDMA, os quais, apesar da ampliação de suas destinaçóes, devem utilizar recursos para a proteção e conservação do meio ambiente.

O presente estudo teve como objetivo a demonstração da importância do princípio da reparação dos danos ambientais e sua aplicabilidade no estado do Amazonas e Município de Manaus, sendo uma das bases para alcançar maior efetividade na prevenção e reparação dos danos ambientais. Conclui-se que, tão importante quanto responsabilizar o infrator e cobrar uma sanção, é o comprometimento que o estado deve ter na aplicação dos recursos oriundos dessa medida, sejam eles de sançóes administrativas ou judiciais, sempre com o objetivo de reparação dos danos ambientais causados, respeitando o meio ambiente, seu equilíbrio ecológico e, principalmente a determinação da Constituição Federal.

\section{Referências}

AMAZONAS. Lei Complementar n. 53, de 5 de junho de 2007. Regulamenta o inciso V do art. 230 e o $\$ 1^{\circ}$ do art. 231 da Constituição Estadual e institui o Sistema Estadual de Unidades de Conservação - SEUC. Disponível em: https:// cetesb.sp.gov.br/proclima/wp-content/uploads/sites/36/2014/08/lei_complementar_n_53_2007_amazonas.pdf. Acesso em: 19 fev. 2021.

AMAZONAS. Lei Complementar n. 187, de 25 de abril de 2018. Disciplina a execução do Art. 220 da Constituição estadual, que institui o Conselho Estadual do Meio Ambiente do Estado do Amazonas - CEMAAM e dispóe sobre o Fundo estadual do Meio Ambiente - FEMA, e dá outras providências. Disponível em: http://meioambiente.am.gov.br/wp-content/uploads/2016/11/CEMAAM-LEI-COMPLEMENTAR-N-187-2c-DE-25-DE-ABRIL-DE-2018.pdf. Acesso em: 19 fev. 2021.

AMAZONAS. Lei n. 1.463, de 7 de outubro de 1981. Obriga as empresas localizadas em territórios do Estado do Amazonas a se responsabilizarem por danos, causados à natureza e dá outras providências. Disponível em: https://sapl.al.am. leg.br/norma/5913. Acesso em: 19 fev. 2021.

AMAZONAS. Lei n. 1.532, de 6 de julho de 1982. Disciplina a Política Estadual da Prevenção e Controle da Poluição, Melhoria e Recuperação do Meio Ambiente 
e da Proteção aos Recursos Naturais, e dá outras providências. Disponível em: https://www.mpam.mp.br/attachments/article/4063/Lei\%20\%201.532-82.pdf. Acesso em: 19 fev. 2021.

AMAZONAS. Lei n. 2.367, de 14 de dezembro de 1995. Altera dispositivos da Lei n. 2.330, de 29 de maio de 1995, e dá outras providências. Disponível em: https://sapl.al.am.leg.br/norma/6822. Acesso em: 19 fev. 2021.

AMAZONAS. Lei n. 2.416, de 22 de agosto de 1996. Dispóe sobre as exigências para concessão da licença para exploração, beneficiamento e industrialização de produtos e subprodutos florestais com fins madeireiros e dá outras providências. Disponível em: http:/www.gret.org/static/cdrom/floresta_viva_amazonas/Files/ Lei_estadual_2416_\%20de_220896.pdf. Acesso em: 19 fev. 2021.

AMAZONAS. Lei n. 2.713, de 28 de dezembro de 2001. Dispóe sobre a política de proteção à fauna aquática e de desenvolvimento da pesca e aqüicultura sustentável no Estado do Amazonas. Disponível em: https://sogi8.sogi.com.br/Arquivo/ Modulo113.MRID109/Registro59057/documento\%201.pdf. Acesso em: 19 fev. 2021.

AMAZONAS. Lei n. 2.908, de 13 de julho de 2004. Dispóe sobre a política de desenvolvimento do ecoturismo e do turismo sustentável no Estado do Amazonas. Disponível em: https://sapl.al.am.leg.br/media/sapl/public/normajuridica/2004/7363/7363_texto_integral.pdf. Acesso em: 19 fev. 2021.

AMAZONAS. Lei n. 2.985, de 18 de outubro de 2005. Regulamenta o Art. 220, $\$$ $1^{\circ}$ e $\$ 2^{\circ}$ da Constituiçáo Estadual, institui o Conselho Estadual de Meio Ambiente do Estado do Amazonas - CEMAAM e dá outras providências. Disponível em: https://sapl.al.am.leg.br/media/sapl/public/normajuridica/2005/7440/7440_texto_integral.pdf. Acesso em: 19 fev. 2021.

AMAZONAS. Lei n. 3.118, de 25 de janeiro de 2007. Institui o Programa Estadual de Educação Ambiental. Disponível em: http://www.pge.am.gov.br/wp-content/uploads/2017/12/Vade-Mecum-.pdf. Acesso em: 19 fev. 2021.

AMAZONAS. Lei n. 3.135, de 5 de junho de 2007. Institui a política estadual sobre mudanças climáticas, conservação ambiental e desenvolvimento sustentável do amazonas, e estabelece outras providências. Disponível em: https://www. legisweb.com.br/legislacao/?id=119995. Acesso em: 19 fev. 2021.

AMAZONAS. Lei n. 3.262, de 30 de maio de 2008. Institui o Grupo Estratégico de Combate a Crimes Ambientais - GECAM. Disponível em: http://www.pge. am.gov.br/wp-content/uploads/2017/12/Vade-Mecum-.pdf. Acesso em: 19 fev. 2021. 
AMAZONAS. Lei n. 3.785, de 24 de julho de 2012. Dispóe sobre o licenciamento ambiental no Estado do Amazonas, REVOGA a Lei n. 3.219, de 28 de dezembro de 2007, e dá outras providências. Disponível em: https://www.legisweb. com.br/legislacao/? id=243659\#: $\sim$ :text=Revogam\%2Dse\%20a\%20Lei\%20 n\%C2\%BA,Art.\&text=Esta\%20Lei\%20entra\%20em\%20vigor,24\%20de\%20 julho\%20de\%202012. Acesso em: 19 fev. 2021.

AMAZONAS. Lei n. 3.789, de 27 de julho de 2012. Dispóes sobre a reposição florestal no Estado do Amazonas. Disponível em: http://www.pge.am.gov.br/wp-content/uploads/2017/12/Vade-Mecum-.pdf. Acesso em: 19 fev. 2021.

AMAZONAS. Lei n. 4.266, de $1^{\circ}$ de dezembro de 2015. Institui a Política do Estado do Amazonas de Serviços Ambientais e o Sistema de Gestão dos Serviços Ambientais, cria o Fundo Estadual de Mudanças Climáticas, Conservação Ambiental e Serviços Ambientais, altera as Leis Estaduais n. 3.135/2007 e 3.184/2007, e dá outras providências. Disponível em: http://online.sefaz.am.gov.br/silt/Normas/Legisla\%E7\%E3o\%20Estadual/Lei\%20Estadual/Ano\%202015/Arquivo/ LE\%204.266_15.htm . Acesso em: 19 fev. 2021.

ANTUNES, P. B. Direito Ambiental. 12. ed. Rio de Janeiro: Lúmen Júris, 2010.

BARBIERI, J. C. Gestão ambiental empresarial: conceitos e modelos e instrumentos. 3. ed. atual. e ampliada. São Paulo: Saraiva, 2001.

BRASIL. Constituição (1988). Constituição da República Federativa do Brasil. Brasília, DF: Senado Federal: Centro Gráfico, 1988.

BRASIL. Decreto n. 1.306, de 9 de novembro de 1994. Regulamenta o Fundo de Defesa de Direitos Difusos, de que tratam os arts. 13 e 20 da Lei n. 7.347, de 24 de julho de 1985, seu conselho gestor e dá outras providências. DF, nov. 1994. Disponível em: http://www.planalto.gov.br/ccivil_03/decreto/1990-1994/D1306. htm\#:-:text=Regulamenta\%20o\%20Fundo\%20de\%20Defesa,gestor\%20e\%20 d\%C3\%A1\%20outras\%20provid\%C3\%AAncias. Acesso em: 19 fev. 2021.

BRASIL. Decreto n. 76.389, de 3 de outubro de 1975. Dispóe sobre as medidas de prevenção e controle da poluição industrial, de que trata o Decreto-Lei n. 1.413, de 14 de agosto de 1975, e dá outras providências. Disponível em: https:// www2.camara.leg.br/legin/fed/decret/1970-1979/decreto-76389-3-outubro-1975-424990-publicacaooriginal-1-pe.html\#:-:text=Em\%20casos\%20de\%20 grave $\% 20$ e,Poder $\% 20 \mathrm{P} \%$ C3\%BAblico $\% 20$ Federal\%20de $\% 20$ determinar. Acesso em: 19 fev. 2021.

BRASIL. Lei n. 4.771, de 15 de setembro de 1965. Institui o novo Código Florestal. 
Disponível em: https://www2.camara.leg.br/legin/fed/lei/1960-1969/lei-477115-setembro-1965-369026-publicacaooriginal-1-pl.html\#: : :text=Fica\%20 proibida $\% 20$ qualquer $\% 20$ forma $\% 20$ de, interesse $\% 20$ p $\%$ C3\%BAblico $\% 20$ pela\%20autoridade\%20florestal. Acesso em: 19 fev. 2021.

BRASIL. Lei n. 6.938, de 31 de agosto de 1981. Política Nacional do Meio Ambiente. Disponível em: https://legislacao.presidencia.gov.br/atos/?tipo=LEI\&numero $=6938 \& a n o=1981 \& a t o=5$ b0UTRE50MrRVT15d. Acesso em: 19 fev. 2021.

BRASIL. Lei n. 7.347, de 24 de julho de 1985. Disciplina a ação civil pública de responsabilidade por danos causados ao meio-ambiente, ao consumidor, a bens e direitos de valor artístico, estético, histórico, turístico e paisagístico (VETADO) e dá outras providências. Disponível em: http://www.planalto.gov.br/ccivil_03/leis/ 17347orig.htm. Acesso em: 19 fev. de 2012.

BRASIL. Lei n. 8.078 de 11 de setembro de 1990. Dispóe sobre a proteção do consumidor e dá outras providências. Disponível em: http://www.planalto. gov.br/ccivil_03/leis/l8078compilado.htm\#:-:text=LEI\%20N\%C2\%BA\%20 8.078\%2C\%20DE\%2011\%20DE\%20SETEMBRO\%20DE\%201990.\&tex$\mathrm{t}=$ Disp\%C3\%B5e\%20sobre\%20a\%20prote\%C3\%A7\%C3\%A3o\%20do\%20 consumidor $\% 20 \mathrm{e} \% 20 \mathrm{~d} \% \mathrm{C} 3 \% \mathrm{~A} 1 \% 20$ outras $\% 20$ provid $\%$ C3\%AAncias. \&text $=$ Art. \&text $=$ Equipara $\% 2$ Dse $\% 20 a \% 20$ consumidor $\% 20$ a,intervindo $\% 20$ nas\%20rela\%C3\%A7\%C3\%B5es\%20de\%20consumo. Acesso em: 19 fev. 2021.

BRASIL. Lei n. 9.008, de 21 de março de 1995. Cria, na estrutura organizacional do Ministério da Justiça, o Conselho Federal de que trata o art. 13 da Lei n. 7.347, de 24 de julho de 1985 , altera os arts. $4^{\circ}, 39,82,91$ e 98 da Lei n. 8.078, de 11 de setembro de 1990, e dá outras providências. Disponível em: http://www.planalto.gov.br/ccivil_03/leis/L9008.htm\#: :text=LEI\%20N\%C2\%BA\%209.008\%2C\%20DE\%2021\%20DE\%20MAR\%C3\%87O\%20 DE\%201995.\&text=Cria\%2C\%20na\%20estrutura\%20organizacional\%20 do, $1990 \% 2 \mathrm{C} \% 20 \mathrm{e} \% 20 \mathrm{~d} \% \mathrm{C} 3 \%$ A $1 \% 20$ outras\%20provid\%C3\%AAncias. Acesso em: 19 fev. 2021.

BRASIL. Lei n. 9.433, de 8 de janeiro de 1997. Institui a Política Nacional de Recursos Hídricos, cria o Sistema Nacional de Gerenciamento de Recursos Hídricos, regulamenta o inciso XIX do art. 21 da Constituição Federal, e altera o art. $1^{\circ} \mathrm{da}$ Lei n. 8.001, de 13 de março de 1990, que modificou a Lei n. 7.990, de 28 de dezembro de 1989. Disponível em: http://www.planalto.gov.br/ccivil_03/LEIS/ L9433.htm. Acesso em: 19 fev. 2021. 
BRASIL. Lei n. 9.605, de 12 de fevereiro de 1998, Dispóe sobre as sançóes penais e administrativas derivadas de condutas e atividades lesivas ao meio ambiente, e dá outras providências, Disponível em: http://www.planalto.gov.br/ccivil_03/leis/ 19605.htm. Acesso em: 19 fev. 2021.

BRASIL. Lei n. 9.795, de 27 de abril de 1999. Dispóe sobre a educação ambiental, institui a Política Nacional de Educação Ambiental e dá outras providências, Brasília, DF, abr. 1999. Disponível em: http://www.planalto.gov.br/ccivil_03/LEIS/ L9795.htm. Acesso em: 19 fev. 2021.

BRASIL. Lei n. 12.305, de 2 de agosto de 2010. Institui a Política Nacional de Resíduos Sólidos; altera a Lei no 9.605, de 12 de fevereiro de 1998; e dá outras providências. Disponível em: https://legislacao.presidencia.gov.br/atos/?tipo $=$ LEI\&numero $=12305 \& a n o=2010 \&$ ato $=e 3 \mathrm{dgXUq1}$ keVpWT0f1. Acesso em: 19 fev. 2021.

BRASIL. Lei n. 12.651, de 25 de maio de 2012. Dispóe sobre a proteção da vegetação nativa; altera as Leis n. 6.938, de 31 de agosto de 1981, 9.393, de 19 de dezembro de 1996, e 11.428, de 22 de dezembro de 2006; revoga as Leis n. 4.771, de 15 de setembro de 1965, e 7.754, de 14 de abril de 1989, e a Medida Provisória n. 2.166- 67, de 24 de agosto de 2001; e dá outras providências. Disponível em: https://www2.camara.leg.br/legin/fed/lei/2012/lei-12651-25-maio-2012613076-norma-pl.html. Acesso em: 19 fev. 2021.

BRASIL. Superior Tribunal de Justiça. Informativo n. 0526, de 25 de setembro de 2013. Segunda Turma. Disponível em: https://www.conjur.com.br/dl/informativo-jurispruencia-salomao-2013.docx. Acesso em: 19 fev. 2021.

BRASIL. Superior Tribunal de Justiça. Recurso Ordinário em Mandado De Segurança: RMS 30812, SP, 2009/0213446-1. Relatora Ministra Eliana Calmon. Julgamento em 4 de março de 2010. Publicado em 18 de março de 2010. Disponível em: http://stj.jusbrasil.com.br/jurisprudencia/19154371/recurso-ordinario-em-mandado-deseguranca -rms-30812-sp-2009-0213446-1. Acesso em: 19 fev. 2021.

CARDIN, V. S. G.; BARBOSA, H. C. Formas de reparação do dano ambiental. Revista de Ciências Jurídicas, Maringá, v. 6. n. 2, p. 155-178, jul./dez. 2008.

FARIAS, C. C.; ROSENVALD, N., BRAGA NETTO, F. P. Curso de Direito Civil - Teoria da responsabilidade civil, responsabilidade civil em espécie. v. 3. Salvador: Juspodivm, 2014. 
FIORILlO, C. A. P. Curso de Direito Ambiental Brasileiro. 14 ed. São Paulo: Saraiva, 2013.

LIMA, A. A. A atuação do IPAAM na gestão ambiental e aplicação da Lei delegada n. 102, de 18 de maio de 2007, de acordo com os aspectos técnicos que determinam o princípio da precaução e eficiência com análise da eficácia e da efetividade do IPAAM. Dissertação (Mestrado) - Programa de Pós-graduação em Direito Ambiental, Universidade do Estado do Amazonas, Manaus, 2016. Disponível em: http://177.66.14.82/handle/riuea/1988. Acesso em: 19 fev. 2021.

MACHADO, P. A. L. Direito Ambiental Brasileiro. 17. ed. rev. atual. e ampl. São Paulo: Malheiros, 2009.

MANAUS. Lei n. 1.192, de 31 de dezembro de 2007. Cria, no município de Manaus, o Programa de Tratamento e Uso Racional das Águas nas edificaçôes - PRO-ÁGUAS. Disponível em: http://semmas.manaus.am.gov.br/wp-content/ uploads/2010/10/lei_pro_aguas.pdf. Acesso em: 19 fev. 2021.

MANAUS. Lei n. 1.358, de 9 de julho de 2009. Estabelece a obrigatoriedade de comprovação da procedência legal da madeira que é utilizada em móveis e instalaçôes fornecidas ao Poder Público, incluindo a administração indireta e dá outras providências. Disponível em: https://www.normasbrasil.com.br/norma/lei-13582009-manaus_175142.html. Acesso em: 19 fev. 2021.

MANAUS. Lei n. 1.451, de 20 de abril de 2010. Dispóe sobre a obrigação dos fabricantes e fornecedores de computadores em receber em suas representaçóes, filiais ou matrizes, para reciclagem, computadores obsoletos descartados pelos consumidores, e dá outras providências. Disponível em: http://dom.manaus.am.gov. br/pdf/2010/abril/DOM\%202429\%2022.04.pdf/view. Acesso em: 19 fev. 2021.

MANAUS. Lei n. 605, de 24 de julho de 2001. Institui o Código Ambiental do Município de Manaus e dá outras providências. Disponível em: https://leismunicipais.com.br/a/am/m/manaus/lei-ordinaria/2001/60/605/lei-ordinaria-n-605-2001-institui-o-codigo-ambiental-do-municipio-de-manaus-e-da-outras-providencias. Acesso em: 19 fev. 2021.

MANAUS. Lei n. 948, de 10 de março de 2006, estabelece normas para a identificação, catalogação e preservação de nascentes d'água no município de Manaus. Disponível em: https://leismunicipais.com.br/a/am/m/manaus/lei-ordinaria/2006/95/948/lei-ordinaria-n-948-2006-estabalece-normas-para-a-identificacao-catalogacao-e-preservacao-de-nascentes-d-agua-no-municipio-de-manaus. Acesso em: 19 fev. 2021. 
MILARÉ, E. Direito do ambiente. 9. ed. São Paulo: Revista dos Tribunais, 2014. MORAES, A. Direito Constitucional. São Paulo: Atlas, 2009.

ORGANIZAÇÃO DAS NACÓES UNIDAS - ONU. Declaração do Rio. Estudos Avançados, São Paulo, v. 6, n. 15, p. 153-159, 1992. Disponível em: http:// www.revistas.usp.br/eav/article/view/9590/11159. Acesso em: 19 fev. 2021.

PADILHA, N. S. O equilíbrio ao meio ambiente do trabalho - direito fundamental do trabalhador e de espaço interdisciplinar. Revista do Tribunal Superior do Trabalho, Brasília, DF, v. 77, n. 4, p. 231-258, out./dez. 2011.

PHILIPPI JR, A. et al. Política e gestão ambiental. In: PHILIPPI JR, A. (Coord.). Curso de Gestão Ambiental. 2 ed. atual. e ampl. Barueri: Manole, 2014. p. 710 711. (Coleção Ambiental, v. 13).

RODRIGUES, M. A. Direito Ambiental esquematizado. 4. ed. São Paulo: Saraiva, 2017.

SENDIM, J. S. C. Responsabilidade civil por danos ecológicos: da reparação do dano através de restauração natural. Coimbra: Coimbra Editora, 1998.

SIRVINSKAS, L. P. Manual de Direito Ambiental. 7. ed. São Paulo: Saraiva, 2009. 